\title{
PENGGUNAAN ZEOLIT ALAM TERAKTIVASI PADA PERBAIKAN KUALITAS MINYAK JELANTAH
}

\author{
Aswita Wirda Ningsih ${ }^{1}$, Emrizal Mahidin Tamboesai' ${ }^{2}$ Akmal Muchtar ${ }^{2}$ \\ 1. Mahasiswa Program Studi S-1 Kimia, Jurusan Kimia \\ 2. Bidang Kimia Anorganik Universitas Riau \\ Fakultas Matematika dan Ilmu Pengetahuan Alam \\ Kampus Bina Widya Pekanbaru, 28293, Indonesia \\ aswita-WN@yahoo.com
}

\begin{abstract}
ABSTRAK
Dalam proses belajar mengajar, konsentrasi menjadi salah satu faktor utama yang mempengaruhi hasil pembelajaran seperti penyerapan materi pelajaran. Konsentrasi menjadi terganggu jika terjadi gangguan akibat faktor-faktor lingkungan, salah satunya adalah kebisingan. Tujuan dari penelitian ini adalah memetakan tingkat kebisingan di Komplek Perguruan Muhammadiyah Kota Pekanbaru dan mengetahui faktor-faktor apa yang mempengaruhi kebisingan. Metode yang digunakan dalam penelitian ini adalah penelitian survei yang bersifat deskriptif yaitu untuk mengetahui gambaran tentang tingkat kebisingan pada Komplek Perguruan Muhammadiyah di Kota Pekanbaru dengan melakukan pengukuran tingkat kebisingan. Hasil penelitian menunjukkan bahwa Komplek Perguruan Muhammadiyah di Kota Pekanbaru memiliki tingkat kebisingan sebesar $69 \mathrm{~dB}$ (A) pada jam belajar dan 54,1 dB (A) pada malam hari. Hasil dari pemetaan intensitas kebisingan pada jam belajar menunjukan tingkat kebisingan tertinggi menyebar dari timur menuju ke barat lokasi penelitian, sedangkan pada malam hari menunjukan tingkat kebisingan tertinggi menyebar dari tenggara menuju ke barat lokasi penelitian dan pusat kebisingan berasal dari jalan KH. Ahmad Dahlan.
\end{abstract}

Kata kunci: Zeolit, minyak jelantah, adsorpsi

\section{PENDAHULUAN}

Zeolit merupakan batuan atau mineral alam yang secara kimiawi termasuk golongan mineral silika dan dinyatakan sebagai alumina silikat terhidrasi, berbentuk halus, dan merupakan hasil produk sekunder yang stabil pada kondisi permukaan karena berasal dari proses sedimentasi, pelapukan maupun aktivitas hidrotermal (Barrer, 1978).

Zeolit banyak diaplikasikan sebagai katalis, resin penukar ion, adsorben, dehidrasi, dan pemisah pada proses pemurnian berbagai bahan dari kontaminannya.

Zeolit yang terdapat di alam masih banyak mengandung zat pengotor yang dapat mengganggu sifat dan kemampuan zeolit sebagai katalis, penukar ion, dan adsorben. Untuk memperoleh zeolit dengan kemampuan yang maksimal, maka diperlukan peningkatan mutu zeolit dengan cara aktivasi dan modifikasi. Aktivasi zeolit dapat dilakukan dengan dua cara yaitu dengan aktivasi secara fisika dan kimia (Evi, 2006).
Mukhlis (2013) menyatakan, zeolit sintesis dengan bahan baku abu dasar batu bara dapat meningkatkan kualitas minyak jelantah. Hasil adsorpsi zeolit sintesis dalam minyak goreng memberikan pengaruh terhadap angka asam, angka penyabunan, dan angka peroksida. Nilai angka asam turun dari $2,9172 \mathrm{mg} \mathrm{OH} / \mathrm{g}$ menjadi $0,3366 \mathrm{mg} \mathrm{OH} / \mathrm{g}$, angka penyabunan naik dari 2,9172 mg KOH/g menjadi 196,911 mg KOH/g dan angka peroksida turun dari 20,8 meq/g menjadi $0,8 \mathrm{meq} / \mathrm{g}$. Dari tiga parameter yang diamati, produk yang dihasilkan memenuhi standar mutu minyak goreng berdasarkan SNI3741-1995 (Winarno, 1997). Namun dikhawatirkan masih terdapat oksida lain dan logam-logam berbahaya yang terkandung dalam bahan baku abu dasar batu bara serta biaya yang dibutuhkan dalam pembuatan zeolit sintesis relatif mahal dan waktu produksi yang cukup lama. Penelitian tentang perbaikan kualitas minyak jelantah juga telah dilakukan oleh Winarni (2010) menggunakan adsorben zeolit alam yang diaktivasi secara kimia. Produk yang 
dihasilkan menunjukkan pengaruh terhadap angka asam dan angka peroksida. Angka asam turun dari 1,423 menjadi $0,245 \mathrm{mg} \mathrm{OH} / \mathrm{g}$, angka peroksida turun dari 8,283 menjadi 6,047 meq $\mathrm{O}_{2} / \mathrm{kg}$ (Winarni, 2010). Peningkatan kualitas minyak jelantah ini penting untuk dipelajari mengingat kurangnya pengetahuan masyarakat terhadap bahaya penggunaan minyak jelantah ini. Minyak jelantah memiliki kandungan asam lemak jenuh yang relatif besar sehingga mudah teroksidasi menjadi senyawa yang membahayakan kesehatan.

\section{METODOLOGI PENELITIAN Alat dan Bahan}

Peralatan yang digunakan dalam penelitian ini adalah ayakan sieve DSTM ukuran 100-200 mesh, oven (Gallenkamp), krusibel, pengaduk magnet, furnace (Gallenkamp), X-Ray Difractometer Maxima $X$ (Shimadzu XRD7000), X-Ray Flourescense (PAN-analytical AXIOS), spektrofotometer infra merah jenis FTIR (Shimadzu IR Prestige 21), Nefelometri Turbidy Unit (Turbidimeter WTW Turb 550), hot plate stirrer thermolyne cimarce 2 (B 212), digital $\mathrm{pH}$ meter, dan peralatan gelas lainnya yang biasa digunakan dilaboratorium.

Bahan- bahan yang digunakan dalam penelitian ini adalah zeolit alam yang di dapat dari PT BRATACO (Cikarang-Bekasi) sedangkan minyak jelantah diperoleh dari penjual gorengan pinggir jalan di daerah Panam kota Pekanbaru. Bahan kimia yang digunakan adalah $\mathrm{KOH}$ (Merck), $\mathrm{Na}_{2} \mathrm{~S}_{2} \mathrm{O}_{3}$ (Merck), KI, $\mathrm{CH}_{3} \mathrm{COOH}$ P.A (Merck), $\mathrm{CHCl}_{3}$ P.A (Merck), alkohol $95 \%$, amilum, fenolfetalein, dan semua bahan berderajat pro analisis kecuali aquades.

\section{Preparasi dan Aktivasi Adsorben}

Adsorben yang digunakan pada proses adsorpsi adalah zeolit alam yang di diperoleh dari PT BRATACO (Cikarang-Bekasi). Sampel berupa zeolit yang telah dihaluskan diayak dengan ayakan 100-200 mesh, zeolit yang tertahan di 200 mesh diambil, aktivasi dilakukan secara fisika dengan memanaskan zeolit pada suhu $300^{\circ} \mathrm{C}$ selama 2 jam dalam furnace untuk memperoleh permukaan zeolit yang lebih luas. Kemudian zeolit dicuci beberapa kali dengan aquades sampai mencapai $\mathrm{pH}$ netral, dan dikeringkan pada suhu $105^{\circ} \mathrm{C}$ di dalam oven untuk membersihkan permukaan pori, membuang senyawa pengotor dan mengatur kembali letak atom yang dipertukarkan. Disimpan dalam desikator dan siap untuk dikarakterisasi.

Uji kualitas dan adsorpsi minyak jelantah

Sampel minyak jelantah ditinjau kualitasnya dari beberapa parameter. Peningkatan kualitas minyak minyak jelantah dipelajari dari parameter bilangan asam bilangan peroksida, dan bilangan iodium. Variabel yang diteliti adalah variasi waktu kontak dari 7 gram zeolit teraktivasi. Sebanyak 250 gram minyak goreng dipanaskan hingga temperatur $105^{\circ} \mathrm{C}$. Ketika minyak mencapai temperatur $70^{\circ} \mathrm{C}$ ditambahkan zeolit teraktivasi kemudian, larutan diaduk menggunakan stirrer magnetic dengan variasi waktu kontak, yakni 30, 60, 90, dan 120 menit.

\section{HASIL DAN PEMBAHASAN}

Analisis komponen kimia penyusun material zeolit alam

Memanaskan zeolit pada suhu $300^{\circ} \mathrm{C}$ selama 2 jam dalam proses aktivasi adalah untuk menguapkan air yang terdapat di dalam zeolit sehingga diperoleh permukaan zeolit yang lebih luas dibandingkan tanpa pemanasan.

Tabel 1: Komponen kimia penyusun material zeolit alam

\begin{tabular}{cc}
\hline Komponen & Persentase (\%) \\
\hline $\mathrm{SiO} 2$ & $75,35 \%$ \\
$\mathrm{~A} 12 \mathrm{O} 3$ & $11,26 \%$ \\
$\mathrm{CaO}$ & $4,91 \%$ \\
$\mathrm{Fe} 2 \mathrm{O} 3$ & $2,84 \%$ \\
$\mathrm{~K} 2 \mathrm{O}$ & $2,01 \%$ \\
$\mathrm{MgO}$ & $1,58 \%$ \\
$\mathrm{TiO} 2$ & $0,52 \%$ \\
$\mathrm{P} 2 \mathrm{O} 5$ & $0,51 \%$ \\
$\mathrm{SO} 3$ & $0,32 \%$ \\
$\mathrm{MnO}$ & $0,02 \%$ \\
\hline \multicolumn{2}{c}{ Sumber: Hasil Analisis Laboratorium } \\
Terpadu MIPA UNS
\end{tabular}

Berdasarkan hasil analisis dapat diketahui bahwa komponen kimia penyusun mineral zeolit 
alam adalah $\mathrm{SiO} 2$ (kuarsa), $\mathrm{Al} 2 \mathrm{O} 3$ (mullit), $\mathrm{CaO}, \mathrm{Fe} 2 \mathrm{O} 3$ (hematit), $\mathrm{K}_{2} \mathrm{O}, \mathrm{MgO}$ dan beberapa oksida lainnya dalam jumlah kecil yang dapat dilihat pada Tabel 1. Didapatkan kandungan unsur $\mathrm{SiO}_{2}$ sebesar 75,35\% dan $\mathrm{Al}_{2} \mathrm{O}_{3}$ sebesar $11,26 \%$. Analisis komponen kimia zeolit mempunyai ciri khusus yaitu jumlah kandungan unsur silika $\left(\mathrm{SiO}_{2}\right)$ yang berkisar antara $75 \%$ $80 \%$, jika lebih dari jumlah tersebut berarti bukan zeolit (Latief, 2004). Zeolit dengan kandungan alumina yang tinggi akan bersifat hidrofilik, sebaliknya zeolit dengan kandungan silika tinggi bersifat hidrofobik, dan biasanya zeolit yang memiliki rasio $\mathrm{Si} / \mathrm{Al}$ yang tinggi memiliki ketahanan termal yang bagus hingga $800^{\circ} \mathrm{C}$ (Flanigen 1980).

Persentase $\mathrm{SiO}_{2}$ yang sebesar 75,35\% mengidentifikasikan bahwa zeolit ini bersifat hidrofobik (non-polar) sehingga dapat dijadikan sebagai adsorben pada perbaikan kualitas minyak jelantah (non-polar).

\section{Karakterisasi zeolit alam teraktivasi dengan XRD}

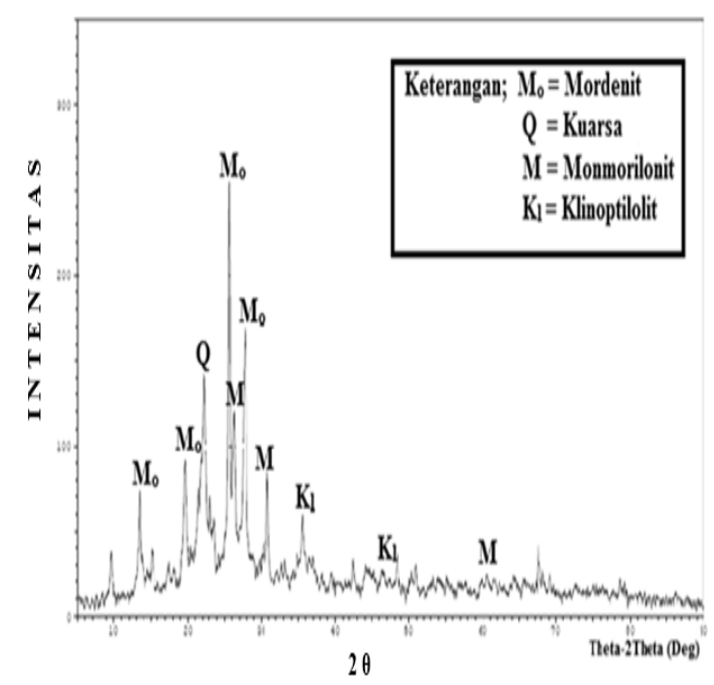

Gambar 1. Diffraksi sinar-X dari zeolit alam

Berdasarkan Gambar 1 diketahui bahwa mineral utama penyusun zeolit alam adalah mordenit pada $2 \theta=25,6405$ dan diikuti dengan puncak pendukung lainnya pada $2 \theta=27,7193$, klinoptilolit pada $2 \theta=22,2211$, mineral lain yang terdapat pada zeolit ini adalah kuarsa yang muncul pada $2 \theta=26,2564$ dan monmorilonit pada $2 \theta=21,8120$, Diffraktogram zeolit menunjukkan bahwa intensitas paling kuat pada jarak antar bidang dasar $\mathrm{d}=3,47149 \AA$ pada $2 \theta$ $=25,6405$. Hal ini menunjukkan bahwa penyusun utama dari zeolit adalah mordenit. Hasil ini sesuai dengan hasil analisis XRD zeolit alam yang telah dilakukan oleh Ratih (2008), yang memperoleh mineral utamanya juga mordenit pada $2 \theta=25,554)$ dan jarak antar bidang $\mathrm{d}=3,35151 \AA$.

Pengaruh adsorpsi zeolit terhadap beberapa parameter minyak goreng

Bilangan asam menyatakan jumlah asam lemak bebas yang terkandung dalam minyak, dan biasanya dihubungkan dengan telah terjadinya hidrolisis minyak berkaitan dengan mutu minyak. Reaksi yang terjadi pada penentuan bilangan asam merupakan reaksi asam dengan basa yang menghasilkan garam.

\section{$\mathrm{RCOOH}+\mathrm{NaOH} \mathrm{RCOOK}+\mathrm{H} 2 \mathrm{O}$}

Minyak jelantah tanpa adsorbsi memiliki bilangan asam $0,9648 \mathrm{mg} \mathrm{KOH} / \mathrm{g}$ yang menunjukkan besarnya derajat kerusakan pada minyak, nilai ini telah melewati ambang batas syarat mutu bilangan asam pada minyak goreng menurut SNI 374:2013, nilai bilangan asam yang diizinkan maksimal sebesar 0,6 mg $\mathrm{KOH} / \mathrm{g}$. setelah proses adsorpsi, penambahan massa adsorben dan waktu kontak memberikan hasil yang linear terhadap penurunan bilangan asam pada minyak jelantah. Semakin banyak massa adsorben yang digunakan semakin rendah bilangan asam yang diperoleh. Bilangan asam paling rendah diperoleh pada penambahan 7 gram zeolit teraktivasi yaitu 0,2292 mg KOH/g.

Pengaruh temperatur yang signifikan terhadap penurunan bilangan asam lemak bebas pada temperatur $120^{\circ} \mathrm{C}$. Hal ini dimungkinkan pada temperatur tersebut adsorben sudah mulai aktif dan tersedianya situs aktif yang lebih banyak pada adsorben. Pada proses adsorpsi ini waktu kontak terbaik untuk penurunan bilangan asam adalah 120 menit. Efisiensi penurunan bilanganasam yang diperoleh adalah 53,5\%. 


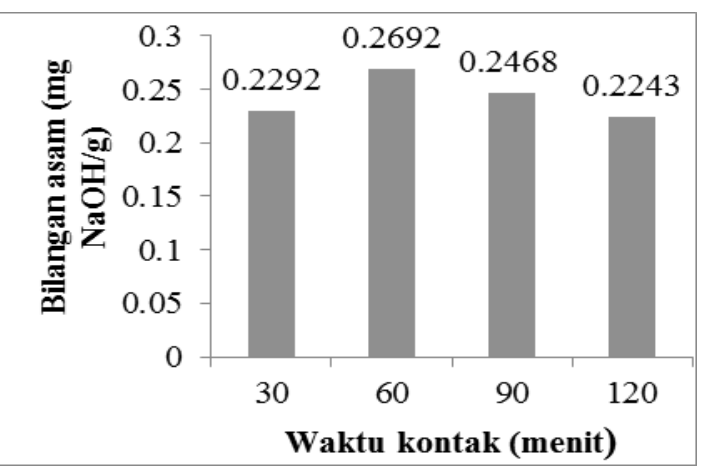

Gambar 2. Pengaruh variasi wakt kontak terhadap bilangan asam minyak jelantah, sebelum adsorpsi 0,9648 $\mathrm{mgNaOH} / \mathrm{g}$ ).

Pada penggunaan waktu kontak 60 menit hingga 120 menit tidak terjadi perubahan nilai bilangan peroksida yang signifikan, terlihat pada Gambar 3. Hal ini disebabkan karena situs aktif pada adsorben telah jenuh sehingga proses adsorbsi menurun sehingga asam lemak bebas bervibrasi sangat kuat sehingga kemampuan situs aktif pada adsorben tidak

mampu untuk mengadsorpsi.

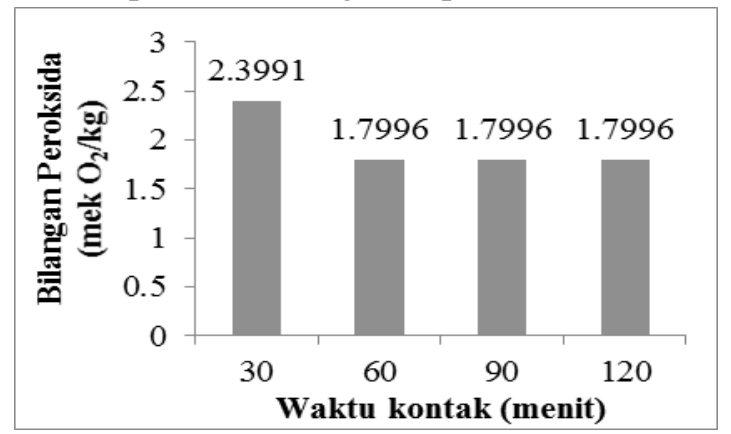

Gambar 3. Pengaruh variasi waktu kontak terhadap bilangan peroksida minyak jelantah, sebelum adsorpsi 7,3981 mek $\mathrm{O}_{2} / \mathrm{kg}$ ).

Bilangan peroksida adalah banyaknya miliekivalen oksigen aktif yang terdapat dalam 1000 gram minyak atau lemak. Syarat mutu bilangan peroksida pada minyak goreng menurut SNI 3741:2013 maksimal sebesar 10 mek O2/g minyak. Bilangan peroksida yang tinggi biasanya mengindikasikan lemak atau minyak sudah mengalami oksidasi. Kemampuan zeolit teraktivasi untuk mengurangi angka peroksida dalam minyak disebabkan oleh adanya gugus silanol (Si-O-H). Zeolit memberikan daya adsorpsi yang cukup besar karena pada zeolit, oksigen penghubung antar dua lapisan silika yang mengapit satu lapisan alumina terikat sangat lemah, ini menyebabkan strukturnya mudah mengembang sehingga peroksida dan molekul air mudah bergerak diantara unit kristal. Peroksida dapat masuk ke dalam struktur dan menggantikan ion hidrogen yang lepas untuk menetralkan muatannya.

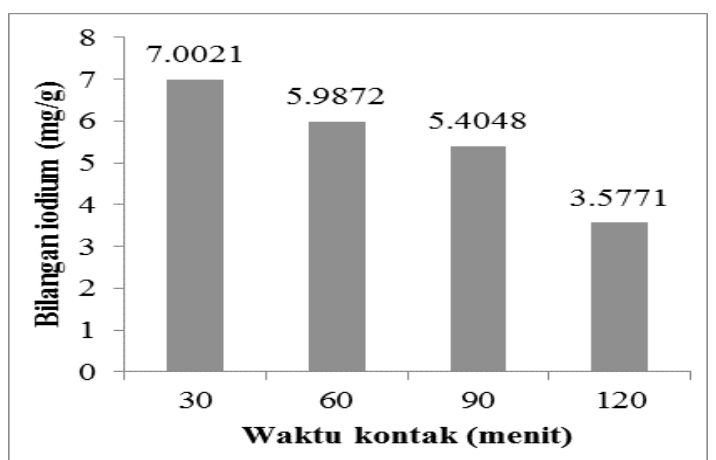

Gambar 4. Pengaruh waktu kontak terhadap bilangan iodium minyak jelantah (bilangan iodium sebelum adsorpsi $10,228 \mathrm{mg} / \mathrm{g}$ ).

Bilangan iodium menunjukkan ketidakjenuhan asam lemak yang menyusun minyak tersebut yang menunjukkan banyaknya ikatan rangkap yang terdapat dalam asam lemak. Reaksi yang terbentuk selama penentuan bilangan iodium ini adalah:

$$
\begin{aligned}
& \mathrm{I}_{2}+2 \mathrm{Na}_{2} \mathrm{~S}_{2} \mathrm{O}_{3} \rightarrow 2 \mathrm{NaI}+\mathrm{Na}_{2} \mathrm{~S}_{4} \mathrm{O}_{6} \\
& \mathrm{BrO}_{3}+6 \mathrm{H}^{+}+6 \mathrm{I}^{-} \rightarrow \mathrm{Br}^{-}+3 \mathrm{I}_{2}+3 \mathrm{H}_{2} \mathrm{O}
\end{aligned}
$$

Pada proses adsorpsi ini waktu kontak terbaik untuk penurunan bilangan iodium adalah 120 menit dengan $7 \mathrm{~g}$ massa adsorben. Efisiensi penurunan bilangan iodium yang diperoleh mencapai $65,2 \%$, seperti yang diperlihatkan pada Gambar 4. Karena pada temperatur tersebut adsorben sudah mulai aktif dan tersedianya situs aktif yang lebih banyak pada adsorben sehingga penurunan bilangan iodiumpun semakin baik

\section{KESIMPULAN}

Berdasarkan hasil pembahasan yang telah dilakukan, dapat disimpulkan:

Zeolit alam yang diaktivasi secara fisika mampu memperbaiki beberapa parameter kualitas minyak jelantah dan memenuhi standar 
mutu minyak goreng berdasarkan SNI 3741:2013.

a. Efisiensi penurunan bilangan asam mencapai 53,5\% dengan menggunakan $7 \mathrm{~g}$ adsorben dengan waktu adsorpsi 120 menit.

b. Efisiensi penurunan bilangan peroksida mencapai 58,6\% dengan menggunakan $7 \mathrm{~g}$ adsorben dengan waktu adsorpsi 30 menit.

c. Efisiensi penurunan bilangan iodium mencapai $65,2 \%$ dengan menggunakan $7 \mathrm{~g}$ adsorben dengan waktu adsorpsi 120 menit.

Zeolit alam teraktivasi yang digunakan pada penelitian ini jika dibandingkan dengan zeolit sintesis pada Mukhlis (2013) yang digunakan untuk tujuan yang sama yaitu untuk memperbaiki beberapa parameter kualitas minyak jelantah, meskipun sama-sama memenuhi Standar Nasional Indonesia namun penggunaan zeolit alam teraktivasi menunjukkan kualitas yang lebih baik

\section{DAFTAR PUSTAKA}

Barrer RM. 1978. Zeolite and Clay Minerals as Sorbents and Molecular Sieve. Academic press. New York.
EVi. 2006. Pemanfaatan Zeolit Aktif dari Turen Malang Untuk Pertukaran Ion Timbal (II), skripsi kimia FMIPA. Universitas Airlangga. Surabaya.

Flanigen EM. 1980. Molecular Sieve Zeolite Technology-The First Twenty-Five Years. Plenary Paper-Technology. Pure Appl Chem 52: 2191-2211. Great Britain: Pergamon Pr.

Latif, N. A. 2004, Eksplorasi Endapan Zeolit di daerah Cikalong, Cipatujah, Karangnunggal, Kabupaten Tasikmalaya, Jawa Barat. Direktorat Sumber Daya Mineral, Direktorat Jenderal Geologi dan Sumber Daya Mineral, Departemen Energi dan Sumber Daya Mineral. Jawa Barat.

Mukhlis. 2013. Sintesis Zeolit dari Abu Dasar Batu Bara Sebagai Adsorben Minyak Goreng Bekas. FMIPA Kimia. UIN Sunankalijaga. Yogyakarta.

Rachmawati, M., Sutarti, M. 1994, Zeolit. Tinjauan Literatur. Pusat Dokumentasi dan Informasi Lembaga Ilmu Pengetahuan Indonesia ( LIPI). Jakarta.

Winarno, F. G. 1992. Kimia Pangan dan Gizi. PT Gramedia Pustaka Utama. Jakarta 